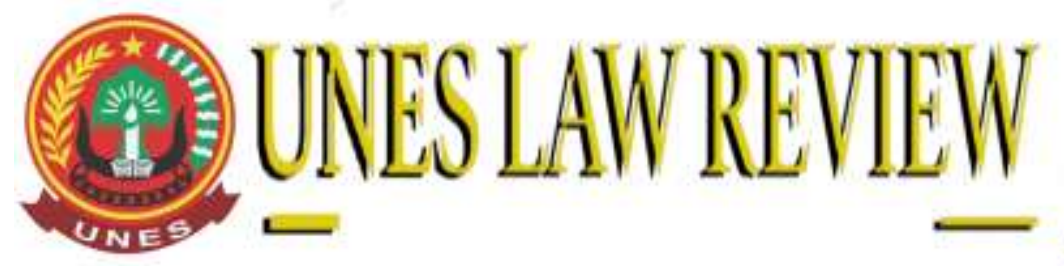

$+6281365118590$ $+6281365118590$

https://review-unes.com/

uneslawreview@gmail.com

DOI: https://doi.org/10.31933/unesrev.v4i2

Diterima: 25/12/2021, Diperbaiki: 06/01/2022, Diterbitkan: 10/01/2022

\title{
PERLINDUNGAN HUKUM TERHADAP DEBITUR DALAM PENARIKAN SITA JAMINAN FIDUSIA TANPA MELALUI LELANG PENGADILAN
}

\author{
Anggi Purnama Tradesa', Zainal Asikin ${ }^{2}$, Eduardus Bayo Sili ${ }^{3}$ \\ 1) Magister Ilmu Hukum, Fakultas Hukum, Universitas Mataram, Indonesia. \\ Email: anggitradesa9@gmail.com \\ 2) Fakultas Hukum, Universitas Mataram, Indonesia. \\ Email: asikinzainal@yahoo.com \\ 3) Fakultas Hukum, Universitas Mataram, Indonesia. \\ Email: eduardbayosili@yahoo.co.id
}

Corresponding Author: Anggi Purnama Tradesa

\section{ABSTRACT}

Debtors as legal subjects are entitled to legal protection, both preventive and repressive, written or unwritten. The legal protection provided is an implementation of the principle of recognition and dignity that is rooted in Pancasila and the Constitution. This study aims to analyze the protection and legal remedies of the debtor in withdrawing the confiscation of fiduciary guarantees without going through a court auction. This research is a normative legal research. The results of this study include: The debtor's legal effort in withdrawing a fiduciary guarantee without going through a court auction is to ask the creditor to show a Fiduciary Guarantee Certificate issued by the Fiduciary Registration Office. If the creditor cannot show a fiduciary guarantee certificate, then the debtor does not need to submit the collateral, because the creditor does not have the right to execute the collateral.

Keywords: Legal Protection, Debtor, Fiduciary Guarantee.

\section{ABSTRAK}

Debitur sebagai subjek hukum berhak mendapatkan perlindungan hukum, baik yang bersifat preventif maupun yang bersifat represif, yang tertulis maupun tidak tertulis. Perlindungan hukum yang diberikan merupakan implementasi atas prinsip pengakuan dan harkat martabat yang bersumber pada Pancasila dan Undang-undang Dasar. Penelitian ini bertujuan untuk menganalisis perlindungan dan upaya hukum pihak debitur dalam penarikan sita jaminan fidusia tanpa melalui lelang pengadilan. Penelitian ini merupakan penelitian hukum normatif. Hasil penelitian ini antara lain: Upaya hukum pihak debitur dalam suatu penarikan sita jaminan fidusia tanpa melalui lelang pengadilan yaitu bisa meminta pihak kreditur untuk menunjukan Sertifikat Jaminan Fidusia yang dikeluarkan oleh Kantor Pendaftaran Fidusia. Jika pihak kreditur tidak 
dapat menunjukkan sertifikat jaminan fidusia, maka debitur tidak perlu menyerahkan barang jaminannya, karena dari pihak kreditur tidak mempunyai hak untuk mengeksekusi barang jaminan tersebut.

Kata Kunci: Perlindungan Hukum, Debitur, Jaminan Fidusia.

\section{PENDAHULUAN}

Jaminan merupakan sesuatu yang diberikan debitur kepada kreditur untuk menimbulkan keyakinan bahwa debitur akan memenuhi kewajiban yang dapat dinilai dengan uang yang timbul dari suatu perikatan. Oleh karena itu, hukum jaminan erat sekali hubungannya dengan hukum benda. ${ }^{1}$ Jaminan yang bersifat kebendaan ini adalah jaminan yang berupa hak mutlak atas sesuatu benda yang mempunyai ciri-ciri dan hubungan langsung atas benda tertentu dari debitur dan dapat dipertahankan kepada siapapun atau mengikuti bendanya serta dapat di alihkan. Salah satu Lembaga Jaminan yang dikenal dalam sistem hukum jaminan di Indonesia adalah Lembaga Jaminan Fidusia. Fidusia berarti penyerahan hak milik atas dasar kepercayaan memberikan kedudukan kepada debitur untuk tetap menguasai barang jaminan, walaupun hanya sebagai peminjam pakai untuk sementara waktu atau tidak lagi sebagai pemilik. Apalagi jaminan fidusia ini dikaitkan dengan pasal 1152 KUH Perdarta menyatkan pula bahwa jika barang jaminan tersebut tetap di kuasai debitur maka jaminan tersebut tidak sah. ${ }^{2}$

Jaminan fidusia dalam kenyataannya adalah usaha pemberian kredit yang menjadi salah satu upaya agar pinjaman yang diberikan kepada debitur dapat dikembalikan dengan lancar. Dalam praktek pelaksanaannya di masyarakat pengikatan objek agunan dengan menggunakan lembaga jaminan fidusia sering digunakan oleh bank maupun perusahaan-perusahaan pembiayaan kendaraann bermotor (finance) dalam suatu perjanjian kredit. Pada prinsipnya dalam suatu perjanjian kredit baik oleh bank maupun oleh perusahaan pembiayaan, pengikatan objek agunan dengan menggunakan lembaga jaminan fidusia adalah dengan tujuan mengamankan asetbank atau perusahaan yang diberikan kepada debitur melalui suatu perjanjian kreditdari resiko debitur tidak mampu mengembalikan hutang-hutangnya kepada pihak bank atau perusahaan pembiayaan tersebut. Dengan demikian dapat dikatakan pengikatan objek agunan dengan menggunakan lembaga jaminan fidusia merupakan suatu perjanjian accesoir, dimana perjanjian kredit yang terlebih dahulu dilaksanakan sebagai perjanjian pokoknya. ${ }^{3}$

Berdasarkan putusan Mahkamah Konstitusi (MK) Nomor 18/PUU-XVII/2019 dimana dalam putusan tersebut Mahkamah Konstitusi menjelaskan bahwa ketentuan larangan eksekusi mandiri tanpa pengadilan pada dasarnya memberikan keseimbangan posisi hukum antara debitur dan kreditur serta menghindari timbulnya kesewenang-wenangan dalam pelaksanaan eksekusi. Dalam putusan Mahkamah Konstitusi (MK) Nomor 18/PUU-XVII/2019 menyatakan terdapat adanya prasa "Cidera janji” yang bertentangan dengan Undang-Undang Dasar Negara Republik

\footnotetext{
${ }^{1}$ Widjaja Gunawan \& Ahmad Yani, Jaminan Fidusia, Raja Grafindo Persada, Jakarta, 2000, hlm. 8.

${ }^{2}$ Winarno Jatmiko, "Perlindungan Hukum Bagi Kreditur Pada Perjanjian Jaminan Fidusia" Jurnal Independent, Vol. 1. Tahun 2013: hlm, 44.

${ }^{3}$ Widjaja Gunawan \& Ahmad Yani, Op., Cit, hlm. 104.
} 
Indonesia tahun 1945 dan tidak mempunyai kekuatan hukum mengikat sepanjang tidak dimaknai bahwa "adanya cidera janji tidak ditentukan secara sepihak oleh kreditur melainkan atas dasar kesepakatan antara kreditur dengan debitur atau atas dasar upaya hukum yang menentukan telah terjadinya cidera janji”. Maka dalam penjelasan pasal 15 ayat 2 Undang-Undang nomor 42 tahun 1999 tentang jaminan fidusia sepanjang prasa "kekuatan eksekutorial" bertentangan dengan Undang-Undang Dasar Negara Republik Indonesia Tahun 1945 dan tidak mempunyai hukum mengikat sepanjang tidak dimaknai "terhadap jaminan fidusia yang tidak ada kesepakatan tentang cidera janji dan debitur keberatan menyerahkan secara sukarela objek yang menjadi jaminan fidusia, maka segala mekanisme dan prosedur hukum dalam pelaksanaan eksekusi sertifikat jaminan fidusia harus dilakukan dan berlaku sama dengan pelaksanaan eksekusi putusan pengadilan yang telah berkekuatan hukum tetap". ${ }^{4}$

Mengingat banyaknya aspek yang dinilai dan aspek-aspek tersebut cukup memberikan keamanan kepada kreditur yaitu pihak bank itu sendiri dalam memberikan kreditur namun pada kenyataannya di akhir abad kedua puluh perbankan Indonesia masa suram dan juga mempunyai andil sebagai penyebab ekonomi Indonesia menjadi tidak menentu. Aspek yang akhirnya sangan mentukan bagi keselamatan usaha perbankan adalah jaminan, namun pada kenyataannya keadaan demikian di perburuk oleh banyaknya nilai jaminan yang jauh di atas harga pasar atau jaminan tidak dapat di eksekusi yang disebabkan oleh status kepemilikan dari barang jaminan yang sudah menjadi milik orang lain sebelum perjanjian kredit ada.

Debitur yang melakukan wanprestasi keterlambatan pembayaran dan objek jaminan di tarik oleh perusahaan telah melanggar pasal-pasal sesuai perjanjian jaminan fidusia antara pihak kreditur dan debitur. Karena pihak kreditur berhak untuk mengambil kembali objek jaminan namun, jika debitur ingin mengambil kembali barang jaminan yang ditarik harus melunasi sesuai ketentuan dari kreditur atau melunasi hutang dari bank atau perusahaan tersebut. Debitur sebagai subjek hukum berhak mendapatkan perlindungan yaitu suatu perlindungan yang diberikan terhadap subyek hukum dalam bentuk perangkat hukum baik yang bersifat preventif maupun yang bersifat represif, baik yang tertulis maupun tidak tertulis. Dengan kata lain perlindungan hukum sebagai suatu gambaran dari fungsi hukum, yaitu konsep dimana hukum dapat memberikan suatu keadilan, ketertiban, kepastian, kemanfaatan dan kedamaian. ${ }^{5}$

Perlindungan hukum yang diberikan bagi rakyat Indonesia merupakan implementasi atas prinsip pengakuan dan perlindungan terhadap harkat dan martabat manusia yang bersumber pada Pancasila dan prinsip Negara Hukum yang berdasarkan Pancasila. Setiap orang berhak mendapatkan perlindungan dari hukum. Hampir seluruh hubungan hukum harus mendapat perlindungan dari hukum. Ketidakjelasan perlindungan hukum bagi para pihak karena terjadinya sita objek jaminan fidusia yang dilakukan oleh perusahaan. Dengan demikian, penting untuk melakukan penelitian terkait dengan adanya kekaburan norma (Vague van Normen) terhadap

\footnotetext{
${ }^{4}$ Putusan Mahkamah Konstitusi (MK) Nomor 18/PUU-XVII/2019 tentang Jaminan Fidusia.

${ }^{5}$ Sudikno Mertokusumo, Penemuan Hukum, Citra Aditya Bakti, Bandung, 2009. hlm. 38.
} 
tanggungjawab bagi pihak yang mengalihkan benda Jaminan Fidusia dalam perjanjian pembiayaan konsumen. ${ }^{6}$

Berdasarkan uraian latar belakang di atas, maka dapat dirumuskan rumusan masalahnya antara lain sebagai berikut: Pertama, Bagaimana perlindungan hukum terhadap debitur dalam penarikan sita jaminan fidusia tanpa melalui lelang pengadilan? Kedua, Bagaimana upaya hukum pihak debitur dalam penarikan sita jaminan fidusia tanpa melalui lelang pengadilan?

\section{METODE PENELITIAN}

Jenis penelitian yang digunakan dalam artikel ini adalah penelitian hukum normatif, yaitu penelitian yang berfokus pada norma hukum positif berupa peraturan perundang-undangan yang merupakan salah satu jenis penelitian yang dikenal umum dalam kajian ilmu hukum. Dalam artikel ini menggunakan dua (2) pendekatan, diantaranya: Pendekatan Undang-undang (statute approach) dan Pendekatan Konseptual (conceptual approach). Jenis dan sumber hukum dalam artikel ini adalah bahan hukum primer, bahan hukum sekunder, dan bahan hukum tersier. Dalam artikel ini dilakukan teknik dan alat pengumpulan bahan hukum dengan studi kepustakaan. Kemudian dalam artikel ini juga digunakan teknik analisa bahan hukum dengan analisis bahan hukum secara komprehensif yaitu melakukan penafsiran (interpretation) terhadap bahan hukum yang dijadikan dasar.

\section{HASIL DAN PEMBAHASAN}

\section{Perlindungan Hukum Terhadap Debitur Dalam Penarikan Sita Jaminan Fidusia Tanpa} Melalui Lelang Pengadilan

Fungsi Hukum menurut Satjipto Raharjo adalah melindungi kepentingan seseorang dengan cara mengalokasikan suatu kekusaan kepadanya untuk bertindak dalam rangka kepentingan tersebut. Pengalokasian kekuasaan ini dilakukan secara terukur, dalam arti ditentukan keluasan dan kedalamannya. ${ }^{7}$ Dalam hal melindungi kepentingan, perlidungan hukum fapat dibedakan menjadi dua yaitu Perlindungan hukum preventif artinya rakyat diberi kesempatan mengajukan pendapatnya sebelum keputusan pemerintah mendapat bentuk yang definitif yang bertujuan untuk mencegah terjadinya sengketa dan perlindungan hukum refrensif yang bertujuan menyelesaikan sengketa. Perlindungan hukum adalah suatu jaminan yang diberikan oleh Negara kepada semua pihak untuk dapat melaksanakan hak dan kepentingan hukum yang dimilikinya dalam kapasitasnya sebagai subyek hukum. ${ }^{8}$

Sebelum membahas tentang perlindungan hukum bagi pihak debitur dalam hal sita jaminan fidusia tanpa melalui pengadilan. Perlu menyinggung makna dari jaminan fidusia. Berdasarkan Pasal 1 angka 2 Undang-Undang Nomor 42 Tahun 1999 tentang Jaminan Fidusia menyatakan bahwa:

"Jaminan fidusia adalah hak jaminan atas benda bergerak baik yang berwujud maupun yang tidak berwujud dan benda tidak bergerak khususnya bangunan yang tidak dapat dibebani

\footnotetext{
${ }^{6}$ Hartono Hadisoeprapto, Pokok-Pokok Hukum Perikatan dan Hukum Jaminan, Liberty, Yogyakarta, 2010. hlm. 18

${ }^{7}$ Sajipto Raharjo, Ilmu Hukum, Citra Aditya Bakti, Bandung, 2006, hlm. 18.

${ }^{8}$ Philipus. M. Hadjon, Perlindungan Hukum bagi Rakyat Indonesia, Bina Ilmu, Surabaya, 1988, hlm. 5.
} 
hak tanggungan sebagaimana dimaksud Undang-Undang Nomor 4 Tahun 1996 tentang Hak Tanggungan atas Tanah beserta Benda-benda yang Berkaitan dengan Tanah yang tetap berada dalam penguasaan pemberi fidusia, sebagai agunan bagi pelunasan utang tertentu, yang memberikan kedudukan yang diutamakan kepada penerima fidusia terhadap kreditur lainnya". 9

Jika dianalisis Pasal 1 angka 2 Undang-Undang Nomor 42 Tahun 1999 tentang Jaminan Fidusia di atas, maka terdapat beberapa unsur yaitu Pertama, terdapat 2 (dua) pihak dalam perjanjian pemberian jaminan fidusia, yaitu pemberi fidusia, baik orang perseorangan atau korporasi pemilik benda yang jadi objek jaminan fidusia dan penerima fidusia, yaiti orang perseorangan atau korporasi yang mempunyai piutang yang dijamin dengan jaminan fidusia (kreditur). Kedua, Objek jaminan fidusia berupa benda bergerak baik berwujud maupun tidak berwujud serta benda tidak bergerak berupa bangunan yang tidak bisa dibebani hak tanggungan. Ketiga, apabila jaminan fidusia terjadi pengalihan hak kepemilikan objek jaminan fidusia atas dasar kepercayaan, tapi objek jaminan fidusia tetap berada dalam penguasaan pemilik benda.

Eksekusi jaminan fidusia diatur dalam Pasal 15 Undang-Undang Nomor 42 Tahun 1999 tentang Jaminan Fidusia sebagai berikut:

Pasal 15:

1. Dalam Sertifikat Jaminan Fidusia sebagaimana dimaksud dalam Pasal 14 ayat (1) dicantumkan kata-kata "DEMI KEADILAN BERDASARKAN KETUHANAN YANG MAHA ESA".

2. Sertifikat Jaminan Fidusia sebagaimana dimaksud dalam ayat (1) mempunyai kekuatan eksekutorial yang sama dengan putusan pengadilan yang telah memperoleh kekuatan hukum tetap.

3. Apabila debitur cidera janji, Penerima Fidusia mempunyai hak untuk menjual Benda yang menjadi objek Jaminan Fidusia atas kekuasaannya sendiri.

Suatu ciri yang sangat menguntungkan bagi kreditur penerima jaminan fidusia adalah, bahwa sertifikat jaminan fidusia mengandung kata-kata yang biasa disebut irah-irah "Demi Keadilan Berdasarkan Ketuhanan Yang Maha Esa” yang terdapat dalam Pasal 15 sub 2 yang dapat ditafsirkan sebagai mengandung titel eksekutorial pada Pasal 15 sub 2 dan hal demikian berarti bahwa sertifikat jaminan fidusia mempunyai kekuatan yang sama dengan suatu keputusan pengadilan yang telah memperoleh kekuatan hukum yang tetap. ${ }^{10}$ Dengan demikian kreditur disini memiliki hak untuk dapat melakukan eksekusi, tanpa adanya putusan pengadilan, tetapi setelah Putusan Mahkamah Konstitusi ini eksekusi harus didasarkan kesepakatan debitur dan kreditur, apabila tidak menemukan kesepakatan maka harus melalui gugatan pengadilan.

Dengan adanya Putusan Mahkamah Konstitusi Repubik Indonesia (MKRI) Nomor 18/PUU/XVII/2019 maka ketentuan dalam Pasal 15 ayat (2) dan ayat (3) dinyatakan inkonstitusional bersyarat. Dengan inkonstitusional Pasal tersebut maka diperlukannya Rekonstruksi Hukum dalam eksekusi sebagai upaya untuk mengembalikan nilai keadilan yang paralel dengan nilai kepastian hukum dalam Undang-Undang Nomor 42 Tahun 1999 Tentang

\footnotetext{
${ }^{9}$ Lihat Pasal 1 angka 2 Undang-Undang Nomor 42 Tahun 1999 tentang Jaminan Fidusia.

${ }^{10}$ J. Satrio, Hukum Jaminan Hak Jaminan Kebendaan Fidusia, Citra Aditya Bakti, Bandung, 2002, hlm. 255.
} 
Jaminan Fidusia. Terdapat 3 poin penting yang perlu diperhatikan terhadap rekontruksi, antara lain:

1. Memelihara inti sarinya asal dengan tetap menjaga watak dan karakteristik hukum tersebut;

2. Memperbaiki hal-hal yang telah runtuh dan memperkuat kembali sendi-sendi yang lemah;

3. Mengisi beberapa pembaharuan tanpa mengubah watak dan karakteristik aslinya. ${ }^{11}$

Konsep yang dikemukan di atas, dalam hal dilakukan eksekusi terhadap jaminan fidusia harus dilakukan penyesuaian dan penyempurnaan baik dari sisi tujuan serta prosedur pelaksanaanya dengan menggunakan nilai keadilan sebagai pencapaian akhir, sehingga relevan diterapkan pada masa sekarang. Sehubungan dengan hal tersebut maka telah diputuskan oleh Hakim Mahkamah Konstitusi Republik Indonesia dengan amar putusaan, diantaranya, mengadili:

1. Menyatakan pasal 15 ayat (2) Undang- Undang Nomor 42 Tahun 1999 Tentang Jaminan Fidusia (Lembaaran Negara Republik Indonesia Tahun 1999 Nomor 168, Tambahan Lembaran Negara Republik Indonesia Nomor 3889) sepanjang frasa "kekuatan eksekutorial" dan frasa "sama dengan putusan pengadilan yang berkekuatan hukum tetap" bertentangan dengan Undang-undang Dasar Negara Republik Indonesia Tahun 1945 dan tidak mempunyai kekuatan hukum mengikat sepanjang tidak dimaknai "terhadap jaminan fidusia yang tidak ada kesepakatan tentang cidera janji (wanprestasi) dan debitur keberatan menyerahkan secara sukarela objek yang menjadi jaminan fidusia, maka segala mekanisme dan prosedur hukum dalam pelaksanaan eksekusi Sertifikat Jaminan Fidusia harus dilakukan dan berlaku sama dengan pelaksanaan eksekusi putusan pengadilan yang telah berkekuatan hukum tetap".

2. Menyatakan Pasal 15 ayat (3) Undang-undang Nomor 42 Tahun 1999 Tentang Jaminan Fidusia (Lembaran Negara Republik Indonesia Tahun 1999 Nomor 168, Tambahan Lembaran Negara Republik Indonesia Nomor 3889) sepanjang frasa "cidera janji" bertentangan dengan Undang-undang Dasar Negara Republik Indonesia Tahun 1945 dan tidak mempunyai kekuatan hukum mengikat sepanjang tidak dimaknai bahwa "adanya cidera janji tidak ditentukan secara sepihak oleh kreditur melainkan atasdasar kesepakatan antara kreitur dengan debitur atau atas dasar upaya hukum yang menentukan telah terjadinya cidera janji”.

3. Menyatakan penjelasan Pasal 15 ayat (2) Undang-Undang Nomor 42 Tahun 1999 Tentang Jaminan Fidusia (Lembaran Negara Republik Indonesia Tahun 1999 Nomor 168, Tambahan Lembar Negara Republik Indonesia Nomor 3889) sepanjang frasa "kekuatan eksekutorial” bertentangan dengan UndangUndang Dasar Negara Republik Indonesia Tahun 1945 dan tidak mempunyai kekuatan hukum mengikat sepanjang tidak dimaknai "terhadap jaminan fidusia yang tidak ada kesepakatan tentang cidera janji dan debitur keberatan menyerahkan secara sukarela objek yang menjadi jaminan fidusia, maka segala mekanismedan prosedur hukum dalam pelaksanaan eksekusi Sertifikat

\footnotetext{
${ }^{11}$ Zaenal Arifin, Rekontruksi Parate Eksekusi Hak Tanggungan. Semarang: Unissula Press, 2006, hlm. 26-27.
} 
Jaminan Fidusia harus dilakukan dan berlaku sama dengan pelaksanaan eksekusi putusan pengadilan yang telah berkekuatan hukum tetap".

Perlindungan hukum bagi pihak debitur dalam eksekusi jaminan fidusia yang melakukan wanprestasi tanpa melalui pengadilan masih belum diatur secara tegas melalui peraturan perundang-undangan yang berlaku. Terlebih jika mengacu pada Pasal 15 Undang-Undang Nomor 42 Tahun 1999 tentang Jaminan Fidusia. Namun sejak dikeluarkannya putusan Mahkamah Konstitusi Republik Indonesia No.18/PUU/XVII/2019, perusahaan Leasing harus lebih berhati-hati melakukan tindakan eksekusi karena berdasarkan ketentuan tersebut, atas kepemilikan sertifikat jaminan fidusia, penerima fidusia (kreditur) berhak mengeksekusi objek jaminan fidusia jika wanprestasi atau cidera janji tidak ditentukan sepihak, melainkan berdasarkan kesepakatan antara kreditur dengan debitur; atau Telah dilakukan upaya hukum tertentu yang menentukan telah terjadinya wanprestasi atau cidera janji.

Selain perlindungan secara preventif melalui dikeluarkannya Putusan Mahkamah Konstitusi Repubik Indonesia (MKRI) Nomor 18/PUU/XVII/2019, perlindungan hukum bagi pihak debitur dalam sita jaminan fidusia tanpa melalui prngadilan terdapat perlindungan secara refresif yaitu dalam hal penyelesaian sengketa apabila terdapat ketidakadilan dalam penarikan jamina fidusia. Adapun bentuk perlidungan tersebut yaitu pihak leasing yang menarik atau mengeksekusi jaminan fidusia dengan tidak memperhatikan aturan dan syarat-syarat yang berlaku dapat diberikan sanksi berdasarkan perbuatan:

1. Perbuatan Melawan Hukum Ps. 1365

Terkait dengan penyimpangan dalam pelaksanaan eksekusi jaminan fidusia, selain dapat melanggar ketentuan hukum pidana yaitu melakukan perbutan main hakim sendiri mencerminkan adanya perbuatan melawan hukum sepertihalnya yang telah diatur dalam pasal 1365 Kitab Undang-Undang Hukum Perdata yang menyatakan bahwa "tiap perbuatan yang melanggar hukum dan membawa kerugian kepada orang lain, mewajibkan orang menimbulkan kerugian itu karena kesalahannya untuk menggantikan kerugian tersebut."

2. Perbuatan Tidak Menyenangkan

Dalam Pasal 335 ayat (1) angka 1 Kitab Undang-undang Hukum Pidana

Pihak debitur yang mendapat perlakuan tidak menyenangkan dengan tindakan sewenangwenang dari perusahaan leasing (kreditur) dapat dikenakan sanksi pasal 335 ayat (1) angka 1 Kitab Undang-Undang Hukum Pidana, yang telah di uji materil ke hadapan Mahkamah Konstitusi Republik Inonesia dengan Nomor putusan 18/PUU-XI/2013 menyatakan bahwa "Barang siapa secara melawan hukum memaksa orang lain supaya melakukan, tidak melakukan atau membiarkaan sesuatu, dengan memakai kekerasan, atau dengan memakai ancaman kekerasan, baik terhadap orang itu disendiri maupun orang lain."

3. Tindak Pidana Pemaksaan Serta Adanya Tindakan Perampasan Ps. 365

Dalam ketentuan pasal 365 ayat 2, 3, dan 4 berlaku bagi kejahatan tersebut. Terhadap perbuatan main hakim sendiri atau perbuatan secara paksa yang dilakukan pihak perusahaan pembiayaan dalam eksekusi Jaminan Fidusia, yang memenuhi maksud dari tindakan yang dimaksud dalam Pasal 365 KUHP. 


\section{Upaya Hukum Pihak Debitur Dalam Penarikan Sita Jaminan Fidusia Tanpa Melalui Lelang Pengadilan}

Terbentuknya lembaga fidusia merupakan suatu lembaga jaminan kebendaan bagi benda bergerak berupa benda modal usaha dengan tidak perlu melakukan penyerahan benda jaminannya dan cukup hanya menyerahkan hak miliknya secara penuh kepercayaan. ${ }^{12}$ Salah satu wujud dari pemberian kepastian hukum hak-hak kreditur adalah dengan mengadakan lembaga pendaftaran fidusia dan tujuan pendaftaran tidak lain adalah untuk menjamin kepentingan dari pihak yang menerima fidusia. ${ }^{13}$ Apabila debitur melakukan pembayaran angsurannya secara tepat waktu sampai dengan adanya pelunasan, maka bank tentu akan memberikan penilaian bahwa debitur tersebut adalah debitur/nasabah dengan predikat baik, sehingga kemudian bank akan lebih percaya untuk kembali memberikan pinjaman kepada debitur dengan predikat baik tersebut. Dari semua transaksi pinjam meminjam/kredit tersebut, tentunya ada juga debitur yang tidak melakukan pembayaran angsuran dengan tepat waktu atau lazimnya disebut kredit macet. Oleh karenanya bank tentu akan berusaha melakukan penagihan kepada debitur dengan alasan menghindari resiko kredit macet.

Untuk melakukan perjanjian fidusia harus dilakukan melalui tahap-tahap pembebanan jaminan fidusia. Yang dimaksud dengan tahap-tahap pembebanan fidusia adalah rangkaian perbuatan hukum dari dibuatnya perjanjian pokok yang antara lain berupa perjanjian pembiayaan konsumen, pembuatan akta jaminan fidusia sampai dilakukannya pendaftaran di Kantor Pendaftaran Fidusia dengan mendapatkan Sertifikat Jaminan Fidusia. ${ }^{14}$

Jaminan fidusia dinyatakan ada pada tanggal dicatatnya jaminan fidusia dalam Buku Daftar Fidusia. Setelah kantor pendaftaran fidusia menerima permohonan pendaftaran fidusia maka akan memuat jaminan fidusia dalam Buku Daftar Fidusia pada tanggal yang sama dengan tanggal penerimaan permohonan pendaftaran. Hari dan tanggal lahirnya jaminan fidusia ini sangat penting karena menandai atau membuktikan lahirnya hak preferen atau hak yang didahulukan bagi kreditur sebagai penerima fidusia sehingga kreditur yang menerima fidusia memiliki kedudukan yang diutamakan atas jaminan fidusia. Kreditur sebagai penerima fidusia yang telah memiliki hak preferen tidak perlu khawatir seandainya pemberi fidusia akan mengalihkan seperti menjual, menyewakan, menjaminkan kembali atau mungkin diletakkan sita jaminan oleh pihak lain, karena undang-undang memberikan perlindungan dan kekuatan hukum bagi penerima fidusia yang memiliki hak preferen dan kreditur sebagai penerima jaminan fidusia dapat mengikuti benda yang menjadi obyek jaminan fidusia dalam tangan siapapun benda itu berada. $^{15}$

\footnotetext{
${ }^{12}$ Djuhaendah Hasan, Lembaga Jaminan Kebendaan Bagi Tanah dan Benda Lain Yang Melekat Pada Tanah Dalam Konsepsi Penetapan Asas Pemisahan Horizontal, PT. Citra Aditya Bakti, Bandung, 1996, hlm. 12.

${ }^{13}$ J. Satrio, Op., Cit, hlm, 143.

${ }^{14}$ Brigita Tesalonika Timbuleng, Upaya Hukum Debitur Terhadap Penarikan Barang Jaminan Oleh Kreditur Dalam Perjanjian Pembiayaan Kendaraan Bermotor Konsumen, Jurnal Lex Et Societatis Vol. VI/No. 10/Des/2018, hlm. 129.

${ }^{15}$ Rudyanti Dorotea Tobing, Hukum Lembaga Pembiayaan, Asas Keadilan dalam Perjanjian Pembiayaan, Lakbang Pressindo, Surabaya, 2017, hlm. 115.
} 
Eksekusi obyek jaminan dalam penarikan sita jaminan dengan jaminan fidusia dilakukan karena terjadi wanprestasi disebabkan ketidakmampuan debitur melakukan kewajibannya sebagai cara penyelesaian terakhir karena upaya penyelamatan tidak berhasil. ${ }^{16}$ Sistem eksekusi jaminan fidusia diatur dalam Undang-Undang Nomor 42 Tahun 1999 tentang Jaminan Fidusia Pasal 29 ayat (1) yang mentukan bahwa: ${ }^{17}$

1. Apabila debitur atau pemberi fidusia cidera janji, eksekusi terhadap benda yang menjadi obyek jaminan fidusia dapat dilakukan dengan cara:

a. Pelaksanaan titel eksekutorial, yang mempunyai kekuatan sama dengan putusan pengadilan yang telah memperoleh kekuatan hukum tetap.

b. Penjualan benda yang menjadi jaminan fidusia atas kekuasaan penerima fidusia sendiri meliputi pelelangan umum serta mengambil pelunasan piutangnya dari hasil penjualan.

c. Penjualan di bawah tangan yang dilakukan berdasarkan kesepakatan pemberi dan penerima fidusia jika dengan cara demikian dapat diperoleh harga tertinggi yang menguntungkan para pihak.

Terdapat perbedaan dalam prosedur pelaksanaan dari ketiga eksekusi jaminan fidusia tersebut di atas yaitu untuk eksekusi yang menggunakan titel eksekutorial berdasarkan sertifikat jaminan fidusia pelaksanaan penjualan benda jaminan tunduk dan patuh pada Hukum Acara Perdata sebagaimana yang ditentukan dalam Pasal 224 H.I.R/258 RBG, yang prosedur pelaksanaanya memerlukan waktu yang lama. ${ }^{18}$ Berbeda dengan pelaksanaan parate eksekusi yang merupakan cara termudah dan sederhana bagi kreditur untuk memperoleh kembali piutangnya, manakala debitur cidera janji dibandingkan dengan eksekusi yang melalui bantuan atau campur tangan Pengadilan Negeri. Bank secara parate eksekusi dapat langsung mengajukan penyitaan harta kekayaan debitur yang dijadikan jaminan kredit dengan pelelangan oleh kantor lelang yang hasil dari penjualan lelang tersebut dapat digunakan untuk pelunasan utang debitur. Selanjutnya penjualan di bawah tangan prosedur pelaksanaanya harus memenuhi beberapa persyaratan antara lain adanya kesepakatan antara pemberi fidusia (debitur) dan penerima fidusia (kreditur). Alasanya untuk memperoleh nilai penjualan yang lebih baik untuk memperoleh harga tertinggi. ${ }^{19}$

2. Debitur yang telah melakukan wanprestasi maka akan menimbulkan akibat hukum bagi para pihak dalam perjanjian. Dalam ketentuan Pasal 1267 KUHPerdata menyebutkan bahwa: ${ }^{20}$

"Pihak terhadap siapa perikatan tidak dipenuhi, dapat memilih apakah ia, jika hal itu masih dilakukan, akan memaksa pihak yang lain untuk memenuhi perjanjian, Ataukah ia akan menuntut pembatalan perjanjian, disertai penggantian biaya kerugian dan bunga"

\footnotetext{
${ }^{16}$ Winda Pebrianti, Tinjauan Hukum Atas Eksekusi Obyek Jaminan Fidusia Melalui Parate Eksekusi Apabila Obyek Jaminan Beralih Kepada Pihak Ketiga Atau Musnah, (Jurnal Supremasi Hukum, Vol. 21, Nomor 1, Januari 2012), hlm. 86.

${ }^{17}$ Undang-Undang Nomor 42 Tahun 1999 tentang Jaminan Fidusia Pasal 29 ayat (1)

${ }^{18}$ Munir Fuady, Jaminan Fidusia, PT. Citra Aditya Bakti, Bandung, hlm 58.

${ }^{19}$ Netty SR Naiborhu, Pelaksanaan Eksekusi Jaminan Berdasarkan Parate Eksekusi oleh Kreditur, Jurnal wawasan Hukum, Vol. 14 No. 8, Juni 2006, hlm. 164.

${ }^{20}$ Kitab Undang-undang Hukum Perdata, Pasal 1267.
} 
Mengenai upaya hukum dari pihak debitur dalam suatu penarikan sita jaminan fidusia tanpa melalui lelang pengadilan yaitu pihak debitur bisa melakukan gugatan perdata tentang penjadwalan hutang kembali dan apabila objek jaminan fidusia telah di eksekusi, maka pihak debitur bisa melakukan monitoring dalam pelaksanaan pelelangan terhadap suatu objek yang dijadikan sebagai jaminan. ${ }^{21}$ Selain itu juga, upaya hukum yang dapat dilakukan oleh pihak debitur terhadap penarikan sita jaminan tanpa melalui lelang pengadilan adalah meminta pihak kreditur untuk menunjukkan Sertifikat Jaminan Fidusia yang dikeluarkan oleh Kantor Pendaftaran Fidusia. Jika pihak kreditur tidak dapat menunjukkan sertifikat jaminan fidusia, maka debitur tidak perlu menyerahkan barang jaminannya, karena dari pihak kreditur tidak mempunyai hak untuk mengeksekusi barang jaminan tersebut. ${ }^{22}$ Langkah selanjutnya adalah melaporkan pihak kreditur tersebut kepada Kementerian Keuangan dalam hal ini, debitur dapat melapor kepada Otoritas Jasa Keuangan, agar perusahaan tersebut dikenakan sanksi sesuai dengan Peraturan Menteri Keuangan. Apabila pihak kreditur dapat menunjukkan Sertifikat Jaminan Fidusia, maka upaya yang dilakukan debitur adalah memantau pelaksanaan penjualan kembali (lelang) barang yang dijadikan jaminan tersebut. Hal ini dilakukan agar debitur mengetahui secara persis berapa harga jual dari barang jaminan, untuk diperhitungkan dengan sisa hutang yang ada. Bila hasil lelang melebihi dari sisa hutang, maka debitur berhak untuk meminta selisihnya. ${ }^{23}$

\section{KESIMPULAN}

Perlindungan hukum bagi debitur dalam eksekusi jaminan fidusia tanpa melalui pengadilan masih belum diatur secara tegas melalui peraturan perundang-undangan yang berlaku. Namun dalam putusan MK. No.18/PUU/XVII/2019, perusahaan Leasing harus lebih berhati-hati melakukan tindakan eksekusi karena berdasarkan ketentuan tersebut, atas kepemilikan sertifikat jaminan fidusia, penerima fidusia (kreditur) berhak mengeksekusi objek jaminan fidusia jika wanprestasi atau cidera janji tidak ditentukan sepihak, melainkan berdasarkan kesepakatan antara kreditur dengan debitur, atau telah dilakukan upaya hukum tertentu yang menentukan telah terjadinya wanprestasi. Jika penyelesaian sengketa terdapat ketidakadilan dalam penarikan jaminan fidusia, terdapat bentuk perlidungan bagi debitur yaitu pihak leasing yang menarik atau mengeksekusi jaminan fidusia dengan tidak memperhatikan aturan dan syarat-syarat yang berlaku dapat diberikan sanksi berdasarkan perbuatan: 1). Perbuatan Melawan Hukum (Pasal 1365 KUHPerdata), 2). Perbuatan Tidak Menyenangkan (Pasal 335 Ayat 1 KUHP), 3) Tindak Pidana Pemaksaan Serta Adanya Tindakan Perampasan (Pasal 365 KUHP). Sedangkan Upaya hukum pihak debitur dalam suatu penarikan sita jaminan fidusia tanpa melalui lelang pengadilan yaitu bisa melakukan gugatan perdata tentang penjadwalan hutang kembali dan apabila objek

21 Daniel Romi Sihombing, Perlindungan Hukum Bagi Debitur Wanprestasi Dalam Eksekusi Jaminan Fidusia Berdasarkan Undang-Undang Nomor 42 Tahun 1999 Tentang Fidusia, Jurnal Hukum Media Justitia Nusantara, Vol. 6 No. 1 Februari 2016: hlm. 38.

${ }^{22}$ Rudyanti Dorotea Tobing, Perlindungan Hukum Terhadap Debitur Akibat Penarikan Barang Jaminan Dalam Perjanjian Pembiayaan Konsumen, Jurnal Morality, Volume 2, Nomor 2, Desember 2015: hlm. 105.

${ }^{23}$ Ibid., 
jaminan fidusia telah di eksekusi, maka pihak debitur bisa melakukan monitoring dalam pelaksanaan pelelangan terhadap suatu objek yang dijadikan sebagai jaminan. Upaya hukum debitur juga bisa meminta menunjukan Sertifikat Jaminan Fidusia yang dikeluarkan oleh Kantor Pendaftaran Fidusia. Jika pihak kreditur tidak dapat menunjukkan sertifikat jaminan fidusia, maka debitur tidak perlu menyerahkan barang jaminannya, karena dari pihak kreditur tidak mempunyai hak untuk mengeksekusi barang jaminan tersebut.

\section{DAFTAR PUSTAKA}

Brigita Tesalonika Timbuleng, Upaya Hukum Debitur Terhadap Penarikan Barang Jaminan Oleh Kreditur Dalam Perjanjian Pembiayaan Kendaraan Bermotor Konsumen, Jurnal Lex Et Societatis Vol. VI/No. 10/Des/2018.

Daniel Romi Sihombing, Perlindungan Hukum Bagi Debitur Wanprestasi Dalam Eksekusi Jaminan Fidusia Berdasarkan Undang-Undang Nomor 42 Tahun 1999 Tentang Fidusia, Jurnal Hukum Media Justitia Nusantara, Vol. 6 No. 1 Februari 2016.

Djuhaendah Hasan, Lembaga Jaminan Kebendaan Bagi Tanah dan Benda Lain Yang Melekat Pada Tanah Dalam Konsepsi Penetapan Asas Pemisahan Horizontal, PT. Citra Aditya Bakti, Bandung, 1996.

Hartono Hadisoeprapto, Pokok-Pokok Hukum Perikatan dan Hukum Jaminan, Liberty, Yogyakarta, 2010.

J. Satrio, Hukum Jaminan Hak Jaminan Kebendaan Fidusia, Citra Aditya Bakti, Bandung, 2002.

Kitab Undang-undang Hukum Perdata.

Munir Fuady, Jaminan Fidusia, PT. Citra Aditya Bakti, Bandung.

Netty SR Naiborhu, Pelaksanaan Eksekusi Jaminan Berdasarkan Parate Eksekusi oleh Kreditur, Jurnal wawasan Hukum, Vol. 14 No. 8, Juni 2006.

Philipus. M. Hadjon, Perlindungan Hukum bagi Rakyat Indonesia, Bina Ilmu, Surabaya, 1988.

Putusan Mahkamah Konstitusi (MK) Nomor 18/PUU-XVII/2019 tentang Jaminan Fidusia.

Rudyanti Dorotea Tobing, Hukum Lembaga Pembiayaan, Asas Keadilan dalam Perjanjian Pembiayaan, Lakbang Pressindo, Surabaya, 2017.

Perlindungan Hukum Terhadap Debitur Akibat Penarikan Barang Jaminan Dalam Perjanjian Pembiayaan Konsumen, Jurnal Morality, Volume 2, Nomor 2, Desember 2015.

Sajipto Raharjo, Ilmu Hukum, Citra Aditya Bakti, Bandung, 2006.

Sudikno Mertokusumo, Penemuan Hukum, Citra Aditya Bakti, Bandung, 2009.

Undang-Undang Nomor 42 Tahun 1999 tentang Jaminan Fidusia.

Widjaja Gunawan \& Ahmad Yani, Jaminan Fidusia, Raja Grafindo Persada, Jakarta, 2000.

Winarno Jatmiko, "Perlindungan Hukum Bagi Kreditur Pada Perjanjian Jaminan Fidusia" Jurnal Independent, Vol. 1. Tahun 2013. 
Winda Pebrianti, Tinjauan Hukum Atas Eksekusi Obyek Jaminan Fidusia Melalui Parate Eksekusi Apabila Obyek Jaminan Beralih Kepada Pihak Ketiga Atau Musnah, (Jurnal Supremasi Hukum, Vol. 21, Nomor 1, Januari 2012).

Zaenal Arifin, Rekontruksi Parate Eksekusi Hak Tanggungan. Semarang: Unissula Press, 2006. 